\title{
PENGARUH DISIPLIN KERJA DAN LINGKUNGAN KERJA TERHADAP KINERJA PEGAWAI KECAMATAN SETU TAHUN 2021
}

\author{
Angga Pratama ${ }^{1}$ \\ Rahmi Andini Syamsuddin ${ }^{2}$ \\ ${ }^{1,2}$ Fakultas Ekonomi, Universitas Pamulang \\ Email: dosen02155@unpam.ac.id; dosen02062@unpam.ac.id
}

\begin{abstract}
This study aims to examine the factors of work discipline and work environment to improve performance in 2021 at the Setu District Office. This study uses an associative approach to determine the relationship between each variable. The data is presented in quantitative data, namely testing and analyzing data by calculating numbers and then drawing conclusions through hypothesis testing. The subjects studied were all permanent employees at the Setu District office as many as 60 employees. The study results concluded that the variables of Work Discipline and Work Environment, which tested partially and simultaneously, had a significant effect on employee performance at the Setu District office. However, the probability of significance was less than 0.05 .
\end{abstract}

Key Words: Discipline, Work Environment, and Employee Performance

\begin{abstract}
ABSTRAK
Penelitian ini bertujuan untuk mengkaji faktor-faktor disiplin kerja dan lingkungan kerja untuk meningkatkan kinerja pada tahun 2021 di Kantor Kecamatan Setu. Penelitian ini menggunakan pendekatan asosiatif untuk mengetahui hubungan antara masing-masing variabel. Data disajikan dalam bentuk data kuantitatif, yaitu menguji dan menganalisis data dengan menghitung angka-angka kemudian menarik kesimpulan melalui pengujian hipotesis. Subyek yang diteliti adalah seluruh pegawai tetap di kantor Kecamatan Setu sebanyak 60 pegawai. Hasil penelitian menyimpulkan bahwa variabel Disiplin Kerja dan Lingkungan Kerja yang diuji secara parsial dan simultan berpengaruh signifikan terhadap kinerja pegawai pada kantor Kecamatan Setu. Namun, probabilitas signifikansinya kurang dari 0,05.
\end{abstract}

Kata kunci: Disiplin, Lingkungan Kerja, dan Kinerja Pegawai 


\section{PENDAHULUAN}

Kedudukan dan peranan Pegawai Negeri Sipil sebagai unsur Aparatur Negara yang bertugas sebagai abdi masyarakat harus menyelenggarakan pelayanan secara adil kepada masyarakat dengan dilandasi kesetiaan dan ketaatan kepada Pancasila dan Undang-undang Dasar 1945 (UU Republik Indonesia, 1999). Penyelenggaraan Pemerintahan memerlukan adanya seorang pemimpin yang selalu mampu untuk menggerakan bawahannya agar dapat melaksanakan tugas dan tanggung jawabnya untuk berpartisipasi dalam kegiatan pemerintahan, pembangunan dan kemasyarakatan secara berdaya guna dan berhasil guna (Maryunis, 2012). Untuk maksud tersebut diperlukan adanya sumber daya manusia yang memiliki kinerja yang baik. Hal ini dikarenakan sumber daya manusia memiliki peranan penting dalam menentukan maju tidaknya suatu instansi (Mambo, 2015), artinya jika suatu instansi memiliki sumber daya manusia yang berkualitas maka instansi itu akan maju dan sebaliknya jika suatu instansi tidak memiliki sumber daya manusia yang berkualitas maka instansi akan sulit untuk maju.

Keberhasilan suatu organisasi dalam mencapai tujuan yang telah ditetapkan sangat ditentukan oleh kualitas orang-orang yang bekerja didalamnya atau yang biasa kita sebut dengan manajemen puncak, manajemen menengah, dan manajemen lini serta bagian non-manajerial yang biasa kita sebut dengan pegawai (Firmansyah \& Mahardhika, 2018). Dalam era informasi ini, pertukaran informasi dalam organisasi akan mengalami perbedaan yang melibatkan serangkaian proses dan memiliki diferensiasi serta pertukaran informasi dalam konteks global (Santoso, Sani, Husain, \& Hendri, 2021). Kondisi ini juga tidak terkecuali dalam penyelenggaran Pemerintahan di wilayah Kabupaten atau bahkan Kecamatan pun juga akan mempengaruhi tingkat kualitas kinerja di dalam instansi.

Penelitian ini difokuskan pada Kantor Kecamatan Setu, yang merupakan salah satu instansi (kantor) yang bergerak di bidang pelayanan Pemerintah. Kegiatan yang dilakukan di Kantor Kecamatan Setu adalah melaksanakan kegiatan pelayanan pemerintah di desa dan sebagai wadah untuk kordinasi dan pemberdayaan masyarakat. Kantor Kecamatan Setu sangat membutuhkan kinerja pegawai yang tinggi untuk meningkatkan kualitas pelayanan terhadap masyarakat, karena dengan memiliki tanggug jawab yang tinggi, rencana kerja yang menyeluruh maka kualitas pelayanan akan meningkat oleh karena itu salah satunya adalah dengan meminimalisir kedisiplinan dan menciptakan lingkungan kerja yang baik serta 
kondusif, prestasi pada sebuah pelayanan masyarakat tidak dapat dilepaskan dari kinerja setiap individu yang terlibat di dalamnya. Manajemen yang baik sangat penting bagi suatu perusahaan untuk mencapai tujuan perusahaan. Kegiatan perusahaan akan berjalan dengan baik jika manusia sumber daya memiliki pengetahuan, keterampilan, dan keinginan untuk mengelola perusahaan sebaik mungkin (Pratama \& Pinasthika, 2021). Dengan meningkatkan kedisiplinan maka pegawai dapat mengerjakan tugasnya dengan cepat dan baik, absensi dapat diperkecil seminimal mungkin, dan ini meningkatkan kinerja. Lingkungan kerja juga tidak kalah pentingnya dalam meningkatkan kinerja pegawai dalam kerangka kerja manajemen SDM.

Kinerja pegawai adalah capaian seorang pegawai dalam bentuk hasil kerja yang dilaksanakan atas tugas yang diberikan kepadanya dalam upaya pencapaian tujuan organisasi yang tidak bertentangan dengan moral dan etika dan sesuai dengan wewenang dan tanggung jawabnya (Rivai, 2015). Kinerja sebagai hasil kerja yang dapat dicapai oleh seseorang atau sekelompok orang dalam suatu organisasi, sesuai dengan wewenang dan tanggug jawab masing-masing dalam upaya mencapai tujuan organisasi bersangkutan secara legal. tidak melanggar hukum dan sesuai dengan moral maupun etika (Sedarmayanti, 2018, hal. 176). Lebih lanjut, peran teknologi sistem informasi juga tidak dapat dipisahkan untuk ditujukan pada aspek sumber daya manusia sehingga kinerja pengelolaan sumber daya manusia dapat lebih terarah dan terukur (Hernita \& Ginanjar, 2021).

Bintoro (2017:107) mengidentifikasi indikator-indikator kinerja antara lain: (1) Kualitas yaitu diukur dari persepsi tenaga pendidik terhadap kualitas pekerjaan yang dihasilkan serta kesempurnaan tugas terhadap keterampilan dan kemampuan tenaga pendidik. (2) Kuantitas yaitu jumlah yang dihasilkan dinyatakan dalam istilah seperti jumlah unit, jumlah siklus aktivitas diselesaikan. (3) Ketepatan waktu yaitu tingkat aktivitas diselesaikan pada awal waktu dinyatakan, dilihat dari sudut koordinasi dengan hasil output serta memaksimalkan waktu yang tersedia untuk aktivitas lain. (4) Efektifitas yaitu tingkat penggunaan sumber daya organisasi (tenaga, uang, teknologi, bahan baku) dimaksimalkan dengan maksud menaikan hasil dari setiap unit dalam penggunaan sumber daya. (5) Kemandirian yaitu tingkat seorang karyawan yang nantinya akan dapat menjalankan fungsi kerjanya komitmen kerja dimana karyawan mempunyai komitmen kerja dengan instansi dan tanggung jawab karyawan terhadap perusahaan dimana dia bekerja.

Faktor disiplin menjadi kunci dan salah penggerak untuk mencapai tujuan organisasi. Menurut Terry, disiplin merupakan alat penggerak karyawan agar setiap pekerjaan dapat berjalan 
dengan lancar, maka harus diusahakan agar ada disiplin yang baik (Sutrisno, 2016, hal. 193). Disiplin juga dapat diartikan sebagai kesadaran dan kesediaan seseorang menaati semua peraturan perusahaan dan norma-norma sosial yang berlaku. Disiplin yang baik mencerminkan besarnya rasa tanggung jawab seseorang terhadap tugas-tugas yang diberikan kepadanya. Hal ini mendorong gairah kerja, semangat kerja, dan terwujudnya tujuan perusahaan, karyawan, dan masyarakat (Hasibuan, 2017). Disiplin kerja adalah suatu alat yang dipergunakan para manajer untuk berkomunikasi dengan karyawan agar mereka bersedia untuk mengubah suatu perilaku serta sebagai suatu upaya untuk meningkatkan kesadaran dan kesediaan seseorang dalam memenuhi segala peraturan perusahaan (Rivai, 2015, hal. 559). Disiplin dapat disimpulkan sebagai bentuk pelatihan yang berusaha memperbaiki dan membentuk pengetahuan, sikap dan prilaku karyawan sehingga karyawan tersebut secara sukarela dan penuh kesadaran mentaati peraturan-peraturan dan norma-norma sosial yang berlaku. Di samping itu, berusaha menciptakan lingkungan kerja yang tertib dan berdaya guna di masa yang akan datang.

Rivai (2015) mengidentifikasi indikator-indikator yang mempengaruhi tingkat kedisiplinan karyawan suatu organisasi antara lain: (1) kehadiran yaitu menjadi indikator yang mendasar untuk mengukur kedisiplinan dan biasanya pegawai yang memiliki disiplin kerja rendah terbiasa terlambat dalam bekerja; (2) ketaatan pada peraturan kerja yaitu pegawai yang taat pada peraturan kerja tidak akan melalaikan prosedur kerja dan akan selalu mengikuti pedoman kerja yang ditetapkan perusahaan; (3) ketaatan pada standar kerja yaitu dapat dilihat dari besarnya tanggungjawab pegawai terhadap tugas yang diamanahkan kepadanya; (4) tingkat kewaspadaan tinggi yaitu pegawai memiliki kewaspadaaan tinggi akan selalu berhati-hati, penuh perhitungan dan ketelitian dalam bekerja serta selalu menggunakan sesuatu secara efektif dan efisien; dan (5) bekerja etis yaitu beberapa pegawai mungkin melakukan tindakan yang kurang sopan ke masyarakat atau terlibat dalam tindakan yang kurang pantas, hal ini merupakan salah satu tindakan indisipliner sehingga bekerja etis merupakan salah satu wujid dari disiplin kerja pegawai (Sinambela, 2019, hal. 335).

Faktor lingkungan kerja juga diidentifikasi memiliki pengaruh untuk mencapai tujuan organisasi dan meningkatkan kinerja pegawai. Lingkungan kerja yang dimaksud antara lain uraian jabatan yang jelas, target yang menantang, pola komunikasi kerja yang efektif, iklim kerja dan fasilitas kerja yang relatif memadai (Mangkunegara, 2017, hal. 17). Lingkungan kerja adalah keseluruhan alat perkakas dan bahan yang di hadapi lingkungan sekitarnya dimana 
seseorang bekerja, metode kerjanya, serta pengaturan kerjanya baik sebagai perorangan maupun sebagai kelompok (Sedarmayanti, 2018, hal. 1). Masalah lingkungan kerja dalam suatu organisasi atau instansi sangatlah penting, dalam hal ini diperlukan adanya pengaturan maupun penataan faktor-faktor lingkungan kerja dalam penyelenggaraan aktifitas organisasi atau instansi (Rohmah, 2019). Kesehatan lingkungan kerja organisasi dan instansi yang baik meliputi semua ruangan, halaman dan area sekelilingnya yang merupakan bagian atau yang berhubunngan dengan tempat kerja untuk kegiatan organisasi atau instansi. persyaratan kesehatan lingkungan kerja dalam keputusan ini di berlakukan baik terhadap organisasi atau instansi yanng berdiri sendiri maupun yang berkelompok.

Sedarmayanti (2019:28) mengidentifikasi indikator-indikator lingkungan kerja dan kutipan dari beberapa sumber diantaranya: (1) Ruang kerja; sebagai pusat kerja setiap karyawan yang melakukan kegiatan kerja, harus selalu dalam keadaan bersih, rapih dan tertata dengan baik untuk menjaga para pegawai bekerja dengan maksimal. (2) Temperatur ruangan adalah kondisi dimana ruangan selalu dalam keadaan sejuk dan tidak panas agar karyawan dapat bekerja dengan baik. Dalam keadaan normal tiap anggota tubuh manusia mempunyai temperatur yang berbeda. Tubuh manusia selalu berusaha untuk mempertahankan keadaan normal, dengan suatu sistem tubuh yang sempurna sehingga dapat menyesuaikan diri dengan perubahan yang terjadi diluar tubuh, tetapi kemampuan menyesuaikan diri tersebut ada batasnya, yaitu bahwa tubuh manusia masih dapat menyesuaikan dirinya dengan temperatur luar jika perubahan temperatur luar tubuh tidak lebih dari $20 \%$ untuk kondisi panas dan 35\% untuk kondisi dingin, dari keadaan normal. Apabila temperatur udara lebih rendah dari 17 derajat celcius maka ini berada dibawah kemampuan tubuh, sebaliknya apabila kegiatan aktivitas tubuh cukup tinggi temperatur udara tidak melebihi dari $27^{\circ} \mathrm{C}$ (Yustini \& Yuliza, 2021, hal. 25). (3) Peralatan kerja yaitu fasilitas kerja disesuaikan dengan ruangan dan pengguna peralatan, seperti dimensi ruangan, meja harus disesuaikan dengan volume ruangan agar para pegawai nyaman dalam bekerja. Perancangan dan perencanaan berdasarkan harga rata-rata para pemakainya. Prinsip ini digunakan apabila perancangan pada harga ekstrim tidak mungkin dilaksanakan karena terlalu mahal. Untuk fasilitas teknologi seperti komputer disesuaikan dengan keperluan perusahaan dan pengguna komputer. Di samping itu, Youyu Hu (2016) menambahkan bahwa pengelolaan SDM dengan sistem dan serta ketersediaan karyawan secara langsung dapat mempengaruhi kualitas karyawan dan juga memiliki peranan dalam pengembangan organisasi (Husain \& Doharma, 2017). (4) Sirkulasi udara yaitu oksigen merupakan gas yang dibutuhkan 
oleh semua makluk hidup untuk menjaga kelangsungan hidup yaitu untuk proses metabolisme. Sirkulasi udara sangat penting dalam suatu ruang kerja yang cukup padat sekalipun ruang tersebut menggunakan pendingin ruangan. Ini dimaksudkan agar oksigen dapat selalu berganti, diperlukan ventilasi udara untuk membuang udara ruangan yang mugkin sudah tidak bersih seperti bau badan dan peralatan yang digunakan seperti komputer dan printer. (5) Keamanan lingkungan kerja harus terbebas dari gangguan kebisingan baik dari kendaraan dan peralatan yang digunakan seperti genset dan peralatan komputer yang terlalu banyak dalam satu ruangan dan mesin pendingin ruangan yang sering penempatannya terlalu dekat dengan jendela sehingga terdengar suara mesinnya. Permasalahan perangkat yang ada ini juga harus diselesaikan sehingga diperlukan suatu sistem yang mendukung kegiatan perusahaan untuk mengurangi risiko keterlambatan penyampaian informasi dan tingkat keamanan yang lemah untuk mentransfer data-data penting perusahaan (Santoso, Sani, Husain, \& Hendri, 2021). Lebih lanjut, kondisi ruangan kerja harus terhindar dari faktor-faktor tersebut agar pegawai tidak merasa terganggu saat bekerja, termasuk hubungan kerja antara karyawan dengan pegawai dan pegawai dengan atasan.

Beberapa masalah yang diidentifikasi pada penelitian ini adalah kinerja pegawai dan potensi bawahan agar mau bekerja secara lebih produktif dan dapat mencapai tujuan instansi yang ditetapkan sebelumnya yaitu faktor disiplin dan lingkungan kerja yang masih harus ditingkatkan di Kantor Kecamatan Setu. Pentingnya potensi pegawai yang tinggi untuk mendukung pencapaian tujuan instansi yaitu kinerja yang baik bagi pegawai khususnya di instansi pada kantor Kecamatan Setu agar dapat membantu melaksanakan tugas dan fungsi secara lebih baik. Oleh karena itu, penelitian ini ditujukan untuk mengkaji faktor disiplin kerja dan lingkungan kerja dalam rangka meningkatkan kinerja pada tahun 2021 di Kantor Kecamatan Setu.

\section{METODE PENELITIAN}

\section{Jenis Penelitian}

Jenis penelitian ini merupakan kategori metode deskriptif dengan pendekatan asosiatif yaitu penelitian yang dilakukan untuk mengetahui nilai variabel mandiri, baik satu variabel atau lebih (independen) tanpa membuat perbandingan, atau menghubungkan dengan variabel yang lain (Sugiyono, 2018, hal. 11). 


\section{Waktu dan Tempat Penelitian}

Lokasi penelitian dilakukan di Kecamatan Setu selama tahun 2021, dan subjek penelitian adalah survei kepada pegawai di Kantor Kecamatan Setu, Kota Tangerang Selatan.

\section{Prosedur Penelitian}

Prosedur penelitian dalam riset survei memerlukan jenis rancangan (experimental design) ke dalam suatu framework. Model proses dilakukan secara terstruktur melalui tahapan yang terjadi dan mengikuti proses dalam menghasilkan informasi penting digunakan sebagai kerangka kerja dan outputnya diperuntukkan agar dapat menjawab tujuan penelitian (Sani, Wiliani, \& Husain, 2019). Model itu sendiri yaitu sesuatu yang sifatnya untuk menggambarkan realitas dan hubungan antar variabel yang saling mempengaruhi (Supranto \& Limakrisna, 2019, p. 31).

\section{Data, Instrumen, dan Teknik Pengumpulan Data}

Data penelitian menggunakan sumber primer dengan perangkat yaitu kuesioner. Penetapan data dalam sampel akhir menggunakan teknik samplingnya yaitu teknik sampling jenuh sebanyak 60 (enam puluh) responden. Pengumpulan data ini ditujukan secara langsung pada objek yang sedang diteliti dengan cara pengisian kuesioner. Skala yang digunakan adalah Likert scale dengan rentang perolehan penilaian tertentu.

\section{Teknik Analisis Data}

Teknik analisis data menggunakan statistik inferensial yaitu metode statistik yang memungkinkan individu untuk melaksanakan uji pengaruh beberapa variabel terhadap variabel lainnya dalam saat yang bersamaan (Santosa, 2019, p. 3). Analisis regresi, analisis koefisien korelasi, analisis koefisien determinasi dan uji hipotesis digunakan untuk mengolah data-data yang telah terkumpul dan membuktikan hipotesis alternatif. Persamaan regresi pada penelitian ini yaitu:

$\mathrm{Y}=\mathrm{a}+\mathrm{b} \mathrm{X}_{1}+\mathrm{b} \mathrm{X}_{2}+\mathrm{e}$

\section{HASIL PENELITIAN DAN PEMBAHASAN}

Hasil Uji Kualitas Instrumen Penelitian 
Kriteria atau syarat keputusan suatu instrumen dikatakan valid dan tidaknya yaitu dengan membandingkan antara r-hitung dengan r-tabel dengan ketentuan jika r-hitung > r-tabel, maka instrument dinyatakan valid atau sebaliknya (Sugiyono, 2018, hal. 173).

Tabel 1 Hasil Uji Validitas masing-masing butir pertanyaan Disiplin Kerja (X1), Lingkungan Kerja (X2), dan Kinerja Pegawai (Y)

\begin{tabular}{ccccll}
\hline \multirow{2}{*}{$\begin{array}{c}\text { Pertanyaan } \\
\text { Ke- }\end{array}$} & \multicolumn{3}{c}{ Skor r-hitung } & \multirow{2}{*}{ Skor r-tabel } & Keterangan \\
\cline { 2 - 4 } & $\mathbf{X 1}$ & $\mathbf{X 2}$ & $\mathbf{Y}$ & \\
\hline 1 & 0,396 & 0,544 & 0,384 & & valid \\
2 & 0,436 & 0,579 & 0,513 & & valid \\
3 & 0,352 & 0,548 & 0,410 & & valid \\
4 & 0,480 & 0,553 & 0,294 & & valid \\
5 & 0,751 & 0,349 & 0,454 & & valid \\
6 & 0,487 & 0,457 & 0,457 & 0,254 & valid \\
7 & 0,780 & 0,696 & 0,708 & & valid \\
8 & 0,692 & 0,596 & 0,679 & & valid \\
9 & 0,677 & 0,628 & 0,695 & & valid \\
10 & 0,422 & 0,637 & 0,600 & & valid \\
\hline
\end{tabular}

Sumber: Data Primer Diolah (2021)

Tabel 1 di atas diperoleh hasil bahwa keseluruhan butir pada 3 (tiga) instrumen yang masingmasing dibangun melalui 10 (sepuluh) butir diketahui memiliki r-hitung yang lebih besar dari rtabel $(0,254)$. Semua butir kuesioner dinyatakan valid dan kuesioner yang digunakan layak untuk diolah sebagai data penelitian.

Kriteria atau syarat keputusan suatu instrumen dikatakan reliabel dan tidaknya yaitu dengan melihat skor Cronbach's Alpha yang harus lebih besar dari 0,60.

Tabel 2 Hasil Uji Reliabilitas Instrumen Penelitian

\begin{tabular}{llc}
\hline \multicolumn{1}{c}{ Variabel } & Cronbach's Alpha (Skor) & Kesimpulan \\
\hline Disiplin Kerja (X1) & 0,730 & Reliabel, \\
Lingkungan Kerja (X2) & 0,752 & karena skor $>0,6$ \\
Kinerja Pegawai (Y) & 0,694 &
\end{tabular}

Sumber: Data Primer Diolah (2021)

Tabel 2 di atas diperoleh hasil bahwa keseluruhan konstruk (variabel) yang diteliti mempunyai nilai Cronbach's Alpha yang lebih besar dari 0,60, hal ini menunjukkan bahwa masing-masing variabel memiliki reliabilitas yang baik. 


\section{Hasil Uji Regresi Linier Berganda}

Tabel 3 Hasil Regresi Linier Berganda

\begin{tabular}{llll}
\hline \multicolumn{1}{c}{ Variabel } & Skor Koefisien Regresi & $\begin{array}{l}\text { Probabilitas } \\
\text { Signifikansi }\end{array}$ & Hasil Uji \\
\hline Constant & 10,362 & 0,003 & \\
Disiplin Kerja & 0,407 & 0,000 & Signifikan \\
Lingkungan Kerja & 0,347 & 0,000 & Signifikan \\
\hline
\end{tabular}

Sumber: Data Primer Diolah (2021)

Tabel 3 di atas menyajikan hasil regresi linier berganda yang dikonversikan ke dalam persamaan regresi:

$\mathrm{Y}=10,362+0,407 \mathrm{X}_{1}+0,347 \mathrm{X}_{2}$

Hasil persamaan regresi dinyatakan sebagai berikut:

$\mathrm{a}=10,362$, konstanta ini berarti jika variabel Disiplin Kerja dan Lingkungan tetap atau konstan maka kinerja bernilai positif.

$\mathrm{b}_{1}=0,407$, Koefisien regresi Disiplin Kerja sebesar 0,407 berpengaruh positif terhadap kinerja pegawai artinya apabila disiplin kerja ditingkatkan maka kinerja pegawai di kantor Kecamatan Setu akan meningkat dengan asumsi Lingkungan Kerja tetap atau konstan.

$\mathrm{b}_{2}=0,347$, Koefisien regresi Lingkungan Kerja sebesar 0,347 berpengaruh positif terhadap kinerja pegawai artinya apabila lingkungan kerja semakin baik maka kinerja pegawai di kantor Kecamatan Setu akan meningkat dengan asumsi disiplin kerja tetap atau konstan.

Tabel 4 Hasil Uji Hipotesis

\begin{tabular}{llll}
\hline \multicolumn{1}{c}{ Variabel } & Skor t-hitung & $\begin{array}{l}\text { Probabilitas } \\
\text { Signifikansi }\end{array}$ & Hasil Uji \\
\hline Disiplin Kerja & 6,889 & 0,000 & Signifikan \\
Lingkungan Kerja & 6,363 & 0,000 & Signifikan \\
\hline
\end{tabular}

Sumber: Data Primer Diolah (2021)

Tabel 4 di atas menyajikan hasil uji hipotesis secara parsial yang diinterpretasikan:

$\checkmark$ Nilai thitung disiplin kerja sebesar 6,889 dengan nilai signifikansi sebesar 0,000 lebih kecil dari $\alpha(0,05)$ yang berarti disiplin kerja berpengaruh signifikan terhadap kinerja pegawai. 
Nilai t hitung lingkungan kerja sebesar 6,363 dengan nilai signifikansi sebesar 0,000 lebih kecil dari $\alpha(0,05)$ yang berarti lingkungan kerja juga berpengaruh signifikan terhadap kinerja pegawai.

Tabel 5 Hasil Uji Simultan (Uji-F)

\begin{tabular}{ll}
\hline & Skor \\
\hline $\mathrm{dF}(1 ; 2)$ & $2 ; 57$ \\
F-statistik & 36,952 \\
Prob. Sig & 0,000 \\
\hline
\end{tabular}

Sumber: Data Primer Diolah (2021)

Tabel 5 di atas menyajikan hasil uji simultan atas pengaruh disiplin kerja dan lingkungan kerja terhadap kinerja pegawai yang memiliki probabilitas signifikansi yaitu 0,000 lebih kecil dari $\alpha$ $(0,05)$ artinya kedua faktor berpengaruh signifikan terhadap kinerja pegawai secara simultan.

\section{Pembahasan}

Hasil perhitungan uji-t atas variabel Disiplin Kerja (X1) menghasilkan probabilitas signifikansi sebesar 0,000 (kurang dari 0,05), maka hipotesis alternatif pertama dapat dibuktikan pengaruhnya secara signifikan, atau dengan kata lain variabel Disiplin Kerja berpengaruh signifikan terhadap Kinerja Pegawai di kantor Kecamatan Setu. Faktor disiplin penting sebagai tools yang dapat menggerakkan karyawan untuk menghasilkan lancarnya kinerja sehingga diperlukan mekanisme disiplin yang baik (Sutrisno, 2016, hal. 193). Disiplin juga dapat membentuk perilaku karyawan sehingga karyawan tersebut secara sukarela dan penuh kesadaran mentaati ketentuan organisasi dan norma-norma sosial yang berlaku.

Hasil perhitungan uji-t atas variabel Lingkungan Kerja (X2) juga menghasilkan probabilitas signifikansi sebesar 0,000 (kurang dari 0,05), maka hipotesis alternatif kedua juga dapat dibuktikan pengaruhnya secara signifikan, atau dengan kata lain variabel Lingkungan Kerja berpengaruh signifikan terhadap Kinerja Pegawai di kantor Kecamatan Setu. Lingkungan kerja juga melekat untuk mencapai peningkatan kinerja pegawai sehingga sangatlah penting, dalam hal ini diperlukan adanya pengaturan maupun penataan faktor-faktor lingkungan kerja dalam penyelenggaraan aktifitas organisasi atau instansi (Rohmah, 2019).

Hasil perhitungan uji-F atas variabel Disiplin Kerja dan Lingkungan Kerja juga menghasilkan probabilitas signifikansi sebesar 0,000 (kurang dari 0,05), maka hipotesis alternatif ketiga juga 
dapat dibuktikan pengaruhnya secara signifikan secara simultan, atau dengan kata lain variabel Disiplin Kerja dan Lingkungan Kerja secara bersama-sama berpengaruh signifikan terhadap Kinerja Pegawai di kantor Kecamatan Setu. Dengan meningkatkan kedisiplinan maka pegawai dapat mengerjakan tugasnya dengan cepat dan baik, absensi dapat diperkecil seminimal mungkin, dan ini menjadi indikator penting untuk meningkatkan kinerja. Lingkungan kerja juga tidak kalah pentingnya dalam meningkatkan kinerja pegawai dalam kerangka kerja manajemen SDM.

\section{KESIMPULAN DAN IMPLIKASI}

Variabel Disiplin Kerja dan Lingkungan Kerja yang dilakukan uji hipotesis baik secara parsial dan simultan berpengaruh signifikan terhadap Kinerja Pegawai di kantor Kecamatan Setu, dimana probabilitas signifikansi kurang dari 0,05. Disiplin kerja harus diperhatikan lagi oleh pimpinan khususnya pada pegawai yang dirasa masih kurang memiliki rasa tanggung jawab yang tinggi dalam bekerja agar pegawai memiliki rasa tanggung yang lebih tinggi dan pada akhirnya dapat meningkatkan kinerja di tahun mendatang. Lingkungan kerja juga agar lebih diperhatikan oleh pimpinan khususnya pada peralatan-peralatan yang digunakan oleh pegawai harus memiliki kualitas yang sudah Standar Nasional Indonesia guna mendukung para pegawai dalam meningkatkan kualitas dan kuantitas kerjanya. Pimpinan instansi juga harus lebih baik memperhatikan dan memberikan motivasi kepada para pegawai agar para pegawai dalam melaksanaan tugas lebih profesional dan lebih mengutamakan kepentingan kantor di atas kepentingan pribadi pegawai.

\section{DAFTAR PUSTAKA}

Arikunto, S. (2016). Prosedur Penelitian Suatu Pendekatan Praktik. Jakarta: Rineka Cipta.

Bintoro, \& Daryanto. (2017). Manajemen Penilaian Kinerja Karyawan. Malang: Gava Media. Firmansyah, A., \& Mahardhika, B. W. (2018). Pengantar Manajemen (Cetakan ke-1). Yogyakarta: Deepublish Publisher.

Hasibuan, M. S. (2017). Manajemen Sumber Daya Manusia (Cetakan ke-18) (Edisi Revisi). Jakarta: PT Bumi Aksara.

Hernita, N., \& Ginanjar, Y. (2021). Managerial Aspect and Digital Marketing of Micro, Small and Medium Enterprises in West Java. IOP Conference Series: Earth and Environmental Science. 748, p. 012035. IOP Publishing. doi:10.1088/17551315/748/1/012035 
$\mathrm{Hu}$, Y. (2016). Design and Implementation of Recruitment Management System Based on Analysis of Advantages and Disadvantages of PHP Three-Tier. The Romanian Review Precision Mechanics, Optics \& Mechatronics(49), 74-79.

Husain, T., \& Doharma, R. (2017). Analisis dan Perancangan Sistem Informasi Recruitment Calon Tenaga Kerja Anak Buah Kapal di PT. Lakemba Perkasa Bahari. KALBISCIENTIA, 4(1), 21-28.

Mambo, R. (2015). Pentingnya Peningkatan Sumberdaya Manusia Dalam Penyelenggaraan Administrasi Perkantoran Pada Kantor Sekretariat Daerah Kabupaten Kepulauan Sangihe. Jurnal Administrasi Publik, 4(35).

Mangkunegara, A. A. (2017). Manajemen Sumber Daya Manusia Perusahaan. Bandung: PT. Remaja Rosdakarya.

Maryunis, R. S. (2012). Upaya Pemerintah Kecamatan Puring Kabupaten Kebumen Dalam Pelaksanaan Pembinaan Dan Pengawasan Penyelenggaraan Administrasi Negara. Yogyakarta: UNY.

Pratama, A., \& Pinasthika, L. G. (2021). The Influence of Work Discipline and Compensation to the Employee Performance: A Case Study of PT Temasindo Intipratama, South Jakarta. European Exploratory Scientific Journal, 5(1), 34-42. Retrieved from https://syniutajournals.com/index.php/EESJ/article/view/201/182

Rivai, V. (2015). Manajemen Sumber Daya Manusia Untuk Perusahaan: Dari Teori ke Praktik (Edisi 3). Jakarta: PT. Raja Grafindo Persada.

Rohmah, R. A. (2019). Analisis Pengaruh Motivasi Kerja Terhadap Kinerja Pegawai. Jurnal Ilmiah Cano Ekonomos, 8(1), 61-70.

Sani, A., Wiliani, N., \& Husain, T. (2019, Desember). Spreadsheet Usability Testing in Nielsen's Model among Users of ITSMEs to Improve Company Performance. European Journal of Scientific Exploration, 2(6), 1-9.

Santosa, A. D. (2019). Analisis Multivariat (Cetakan Ketiga) (Edisi Ketiga). Yogyakarta: Penerbit Kepel Press.

Santoso, B., Sani, A., Husain, T., \& Hendri, N. (2021). VPN Site To Site Implementation Using Protocol L2TP And IPSec. TEKNOKOM : Jurnal Teknologi dan Rekayasa Sistem Komputer, 4(1), 30-36. doi:10.31943/teknokom.v4i1.59

Sedarmayanti. (2018). Manajemen Sumber Daya Manusia; Reformasi Birokrasi dan Manajemen Pegawai Negeri Sipil (Cetakan 10). Bandung: PT. Reflika Aditama.

Sinambela, L. P. (2019). Reformasi Pelayanan Publik Teori, Kebijakan dan Implementasi (Cetakan 10). Jakarta: Bumi Aksara.

Sugiyono. (2018). Metode Penelitian Evaluasi: Pendekatan Kuantitatif, Kualitatif, dan Kombinasi. Bandung: CV. Alfabeta.

Supranto, J., \& Limakrisna, N. (2019). Petunjuk Praktis Penelitian Ilmiah untuk Menyusun Skripsi, Tesis dan Disertasi (Edisi 5). Bogor: Penerbit Mitra Wacana Media. 
Angga Pratama, Rahmi Andini Syamsuddin Vol 6 No 1

ISSN : 2541-6995

E ISSN : 2580-5517

Sutrisno, E. (2016). Manajemen Sumber Daya Manusia (Cetakan ke-8). Jakarta: Kencana Prenada Media Group.

UU Republik Indonesia. (1999). Undang-Undang Republik Indonesia Nomor 43 Tahun 1999 tentang Perubahan atas Undang-Undang Nomor 8 Tahun 1974 tentang Pokok-Pokok Kepegawaian. Jakarta. Retrieved from https://www.dpr.go.id/dokjdih/document/uu/444.pdf

Yustini, T., \& Yuliza. (2021). Manajemen Sumber Daya Manusia: Analisis Kajian di Masa Pandemi Covid-19 (Cetakan Pertama). Malang: CV. Literasi Nusantara Abadi. 